\title{
Sociálny kapitál a triedy v slovenskej spoločnosti ${ }^{1}$
}

\author{
Ján Sopóci ${ }^{2}$ - Anna Hrabovská ${ }^{3}$ \\ Katedra sociológie FiF UK Bratislava
}

\begin{abstract}
Social Capital and Classes in Slovak Society. In this article we analyze data from the International Social Survey Programme, module Social Networks and Social Resources 2017 to identify the relationship between social capital and social classes in Slovakia. According to the work of Florian Pichler and Claire Wallace, we are focusing on different dimensions of social capital (authors distinguished formal and informal capital, with their extensivity and intensivity). Using the method of ordinal regression analysis we found out, that social class is an important element in understanding social capital in Slovak society. Upper classes have higher levels of social capital (both formal and informal capital) than middle classes and lower classes, although informal capital was not as clearly stratified by class.

Sociológia 2019, Vol. 51 (No. 5: 502-524)

https://doi.org/10.31577/sociologia.2019.51.5.21
\end{abstract}

Key words: Social capital; formal and informal capital; class; European socioeconomic classification; class homology; social networks

\section{Úvod}

Rešpektovanie sociálnej triedy ako faktora životnej úrovne, spôsobu života, materiálnej a kultúrnej spotreby i mnohých d'alších charakteristík l'udí je aj v súčasnosti typické pre väčšinu sociologických teórií sociálnych nerovností. Komplexným vysvetlením spôsobov a mechanizmov pôsobenia triednej determinácie sociológovia však doteraz nedisponujú a na objasnenie týchto otázok poskytujú rôzne, často i vel'mi diferencované stanoviská. K najrozšírenejším patrí stanovisko, resp. model triednej homológie, ktoré v zásade tvrdí, že rôzne sociálne triedy, ktoré zostávajú významnými spoločenskými aktérmi, majú osobitné a navzájom odlišné charakteristiky, ako sú objem a vzory spotreby, štýl života, kultúrna úroveň atd'., ktoré spoluurčujú ich pozíciu v systéme sociálnej stratifikácie. Pomerne rozšírené je i protikladné stanovisko, označované ako postmoderné či individualistické, ktoré tvrdí, že vo vyspelých moderných spoločnostiach sociálne triedy už stratili svoj niekdajší význam a v súčasnosti už neovplyvňujú život spoločností a ich členov tak ako v minulosti - životy členov súčasných spoločností ovplyvňujú najmä ich individuálne charakteristiky, ako sú vek, rod, vzdelanie, etnicita a pod.

Medzi najvýznamnejších protagonistov stanoviska homológie sociálnotriednej štruktúry a spôsobu života patril Pierre Bourdieu, podl'a ktorého je táto

\footnotetext{
1 Štúdia vznikla v rámci riešenia výskumnej úlohy APVV-14-0527.

${ }^{2}$ Korešpondencia: prof. PhDr. Ján Sopóci, PhD., Katedra sociológie, FiF UK, Gondova 2, 81499 Bratislava, Slovensko. Email: jan.sopoci@uniba.sk

${ }^{3}$ Korešpondencia: RNDr. Anna Hrabovská, PhD., Porubského 8, 81106 Bratislava. E-mail: hrabovska@ chello.sk
} 
homológia sprostredkovaná predovšetkým sociálno-triednym habitom (sociálne vytvoreným, špecifickými triednymi podmienkami formovaným systémom dispozícií členov jednotlivých tried, na základe ktorého vnímajú i hodnotia svet a konajú v ňom). Tento systém dispozícií závisí od ich postavenia v spoločnosti, čiže na tom, akým kapitálom, presnejšie akými druhmi a vel'kost'ou kapitálu disponujú (za kapitál považoval Bourdieu akýkol'vek zdroj použitel'ný v niektorej sociálnej oblasti na dosiahnutie osobného profitu a rozlišoval ekonomický, kultúrny, sociálny a symbolický kapitál). Na základe odlišných triednych habitov vznikajú osobitné spôsoby života, kultúrnej spotreby, vkusu i d’alších charakteristík jednotlivých sociálnych tried. Takto sa v rámci triednej štruktúry vytvárajú konzistentné a navzájom odlišné spôsoby života tried, na základe ktorých vzniká a reprodukuje sa aj ich hierarchické usporiadanie v systéme sociálnej stratifikácie. Toto usporiadanie je pol’om symbolického triedneho zápasu, v ktorom sa príslušníci jednotlivých sociálnych tried vymedzujú voči ostatným členom spoločnosti. Súperenie medzi sociálnymi triedami na poli spôsobu života a kultúry považoval P. Bourdieu za základnú súčast' triedneho boja a kultúrnu reprodukciu uskutočňovanú prostredníctvom využívania symbolického násilia chápal a skúmal ako podstatný aspekt reprodukcie sociálno-triednej stratifikácie spoločnosti (Bourdieu 1987). Osobitnú pozornost' pritom venoval aj úlohe sociálneho kapitálu v procese reprodukcie spoločenských tried a systému nerovností vo Francúzsku.

Vd'aka Bourdieuho dielu sa problematika sociálneho kapitálu dostala od osemdesiatych rokov 20. storočia do centra záujmu sociológov a najmä na základe rôznych modifikácií významu tohto pojmu a jeho využitia v mnohých empirických výskumoch sociálnych sietí a sociálnej súdržnosti zaznamenal $\mathrm{v}$ d'alších dvoch desatročiach široký rozmach a uplatnenie vempirickom skúmaní i teoretických analýzach moderných spoločností (Coleman 1990; Halpern 2005; Lin 2001a,b; Lin - Fu - Hsung 2001; Lin - Fu - Chen 2014; Putnam 1994, 2000 atd'.). Paradoxne sa pritom v rámci tejto sociologickej konjunktúry využívania koncepcie sociálneho kapitálu ako východiska množstva výskumov a analýz západných spoločností nedostalo náležitej pozornosti otázkam, na objasnenie ktorých Bourdieu koncepciu kapitálu (vrátane sociálneho) vytvoril: teda otázkam sociálnej stratifikácie, reprodukcie sociálnych nerovností a skúmaniu vzt’ahu medzi spoločenskou triedou a sociálnym kapitálom.

Toto zanedbávanie skúmania uvedenej problematiky, ktoré je pre svetovú sociológiu typické až do súčasnosti, sa týka aj nášho sociologického bádania, v rámci ktorého sa však i skúmaniu sociálneho kapitálu zatial' venovala len 
malá pozornost ${ }^{4}$. Ciel’om tejto štúdie je prispiet' k zvýšeniu záujmu slovenskej sociológie o zatial' nepreskúmané aspekty sociálneho kapitálu a priniest' odpoved' na jednu zo základných otázok spojených s problematikou sociálneho kapitálu: ako možno charakterizovat' vzt'ah medzi spoločenskou triedou a sociálnym kapitálom v súčasnej slovenskej spoločnosti? Na základe údajov získaných reprezentatívnym empirickým výskumom ${ }^{5}$ otestujeme platnost' uvedených protikladných stanovísk, vysvetl'ujúcich odlišnými spôsobmi vzt'ah medzi spoločenskou triedou a sociálnym kapitálom. V d’alšom texte najskôr stručne predstavíme rôzne chápania sociálneho kapitálu a tiež základné chápania vzt’ahu medzi triedami a sociálnym kapitálom. Potom vysvetlíme spôsob, ktorým otestujeme ich platnost' v slovenskej spoločnosti. Ďalej sa budeme venovat' prezentácii zistení výskumu a analýze výsledkov uskutočneného testovania, ako aj záverečnému zhodnoteniu použitého postupu a dosiahnutých výsledkov.

\section{Sociálny kapitál a spoločenské triedy}

Téme sociálneho kapitálu bola venovaná vel'ká pozornost' nielen v sociológii, ale i v politológii, ekonómii a d’alších vedách najmä v posledných troch desat'ročiach. Problematike súvisiacej so sociálnym kapitálom sa však mnohí autori z oblasti spoločenských vied venovali už pred vytvorením a etablovaním sa tohto pojmu. Uvažovanie o téme sociálneho kapitálu je súčast’ou dlhodobého vedeckého diskurzu, ktorý bol venovaný na jednej strane otázkam demokracie, občianskej spoločnosti a občianskej participácie, a na druhej strane otázkam sociálnych interakcií, väzieb a sociálnych sietí.

Diskurz, ktorého t’ažiskom je problematika občianskej spoločnosti a občianskej participácie, iniciovali už klasickí autori, ako napríklad Alexis de Tocqueville; v súčasnosti sú jeho najvýznamnejšími aktérmi Robert Putnam, David Halpern, Francis Fukuyama i d’alší autori, ktorí považujú občiansku participáciu a občianske združovanie za základ upevňovania demokracie i za dôležitý predpoklad udržiavania spoločenskej prosperity. Stúpenci tohto prístupu sa zameriavajú predovšetkým na skúmanie spôsobov, ktorými občianska participácia na verejnom živote vytvára spoločenský, resp. kolektívny sociálny kapitál, a to najmä prostredníctvom vytvárania a využívania občianskych združení a zapájaním sa radových občanov do riešenia verejných záležitostí (Fukuyama 1995, 1999; Halpern 2005; Putnam 1994, 2000; Tocqueville 1992).

\footnotetext{
${ }^{4}$ Niektorým aspektom tejto problematiky sa v SR venovali napríklad Z. Kusá (Kusá 1997), S. Konečný (Konečný 2004), G. Lubelcová (Lubelcová 2010). V ČR bola táto téma v centre intenzívneho a systematického záujmu sociológov už pred pätnástimi rokmi (Matějů - Vitásková 2006; Šafr - Sedláčková 2006; Keller 2009).

${ }_{5}^{5}$ Ide o výskum ISSP, modul Sociálne siete 2017.
} 
Diskurz sústred’ujúci sa na otázky sociálnych interakcií, vzt'ahov, väzieb a sociálnych sietí je spojený už s dielami zakladatel'ov sociológie; od sedemdesiatych rokov 20. storočia ho rozvíjali najmä Pierre Bourdieu, James Coleman a analytici sociálnych sietí, ako sú Mark Granovetter, Nan Lin a mnohí d’alší. Títo autori zdôrazňujú najmä význam neformálnych väzieb a vzt’ahov medzi l'ud'mi, pričom ako teoreticko-metodologické východisko svojho prístupu využívajú najčastejšie metodologický individualizmus a teóriu racionálnej vol'by. Na rozdiel od stúpencov prvého prístupu nezdôrazňujú celospoločenskú perspektívu a spoločenský úžitok, ale naopak individuálnu perspektívu a užitočnost' sociálnych väzieb a sociálnych sietí pre jednotlivcov (Bourdieu 1987; Bourdieu - Passeron 1977; Coleman 1990; Granovetter 1973, 1974; Lin 1999, 2001a; Paxton 1999).

Na základe odlišností týchto dvoch častí diskurzu, ich východiskových perspektív i rôznosti teoretických záverov, ku ktorým dospeli ich predstavitelia, sa v súčasnosti rozlišujú dve základné chápania sociálneho kapitálu: individuálne a kolektívne chápanie, ktoré sa odlišujú z hl'adiska nositel'ov sociálneho kapitálu, spôsobov jeho utvárania i jeho efektov (Sedláčková - Šafr 2012; Šafr - Sedláčková 2006). Individuálny kapitál je najčastejšie chápaný ako zo štruktúry sociálnych vzt’ahov a väzieb vyplývajúci nehmotný zdroj, resp. majetok jednotlivca, ktorý si ho $\mathrm{v}$ sociálnych interakciách systematicky vytvára a udržiava ako siet' kontaktov, známostí a vzt'ahov s inými osobami, ktoré môže využit' vo svoj prospech, resp. na svoj úžitok. Kolektívnym kapitálom sa obyčajne chápe súhrn charakteristík sociálnej organizácie, ako sú vzt’ahy súdržnosti a vzájomnej dôvery, sociálne normy a siete umožňujúce efektívnu spoluprácu $\mathrm{v}$ sociálnych skupinách i v spoločnosti, ktorá prináša nielen individuálny, ale i kolektívny úžitok.

Niektorí autori sa domnievajú, že tieto dva druhy sociálneho kapitálu sú prepojené a môžu sa navzájom pozitívne ovplyvňovat' či podporovat' (Kadushin 2012). Mnohí teoretici však upozornili, že to nemusí vždy platit' a že existencia sociálnych sietí a vzt'ahov vzájomnej podpory môže spôsobit', resp. znamenat' i prevahu klientelistických, nepotistických a mafiánskych vzt'ahov, ktoré nahradia demokratickú občiansku participáciu a na demokratických princípoch založené neformálne občianske združenia (Portes 1998). Súčasne treba upozornit' na skutočnost', že snaha o prepájanie či zlučovanie týchto dvoch druhov sociálneho kapitálu je snahou o spájanie nesúrodých, ba až nezlučitel'ných prístupov, na základe ktorých boli vytvorené pojmy individuálny a kolektívny kapitál: v prípade individuálneho kapitálu je jeho určujúcou charakteristikou individualistické racionálne kalkulovanie s ciel'om investovat' do sociálnych sietí pre dosahovanie vlastného prospechu, v prípade kolektívneho kapitálu sú jeho určujúcimi charakteristikami skupinové alebo celospoločenské vzt’ahy solidarity, súdržnosti, vzájomnej podpory, dôvery a 
dosahovanie kolektívneho úžitku (Keller 2009). Na základe toho viacerí autori poukázali na fakt, že princíp kapitálu v pôvodnom význame tohto termínu je obsiahnutý iba v pojme individuálneho kapitálu, ale nie v pojme kolektívneho kapitálu a preto je v tomto prípade problematické termín kapitál vôbec používat' (Bevort - Lallement 2006; Keller 2009). Sociálnym kapitálom v „pravom zmysle" tohto slova je teda iba individuálny kapitál.

Rešpektujúc uvedené stanovisko považujeme preto za teoreticky vhodnejšie a pre účely empirického skúmania sociálneho kapitálu aj výhodnejšie používat' termíny formálny a neformálny sociálny kapitál, ktoré vytvorili Florian Pichler a Claire Wallace (Pichler - Wallace 2007, 2008). Aj táto klasifikácia druhov sociálneho kapitálu pritom vychádza zo spomínaných dvoch druhov diskurzu. Termín formálny kapitál vychádza z diskurzu sústred’ujúceho sa na občiansku participáciu a združovanie a označuje združovanie sa l'udí do formálnych skupín, najmä rôznych občianskych združení, spolkov a organizácií. Termín neformálny kapitál vychádza $\mathrm{z}$ diskurzu sústred’ujúceho sa na neformálne sociálne väzby a vzt'ahy a označuje neformálne sociálne vzt’ahy a siete medzi l'ud'mi'.

Pichler a Wallace využili svoje rozlíšenie dvoch druhov sociálneho kapitálu na preskúmanie vzt’ahu medzi sociálnym kapitálom a spoločenskými triedami. V tejto súvislosti treba znovu pripomenút: napriek tomu, že termín sociálny kapitál sa dostal do centra záujmu sociológov najmä vd’aka dielu P. Bourdieu, ktorý ho vytvoril a používal pri svojom skúmaní procesu reprodukcie sociálnych tried vo Francúzsku, v d'alších desatročiach sociológovia nevenovali skúmaniu vzt’ahu medzi triedami a sociálnym kapitálom dostatočnú pozornost'. Bourdieu rozlíšil pre potreby skúmania reprodukcie sociálnych nerovností viaceré druhy, resp. formy kapitálu (ekonomický, kultúrny, sociálny, symbolický), pričom jednotlivé sociálne triedy diferencuje nielen súhrnné množstvo jednotlivých druhov kapitálu, ktorým disponujú, ale aj zloženie tohto celkového kapitálu. Sociálne triedy (najmä privilegované) sú schopné udržiavat' si svoju spoločenskú pozíciu nielen vd’aka vlastneniu ekonomického kapitálu, ale aj prostredníctvom zvel'ad'ovania a využivania svojho kultúrneho kapitálu (kultúrnej spotreby) a prostredníctvom budovania a udržiavania sociálnych sietí a vzt’ahov, čiže sociálneho kapitálu. Sociálny kapitál Bourdieu chápal ako „množinu aktuálnych alebo potenciálnych zdrojov, ktoré vychádzajú z vlastnenia trvalej siete viac či menej inštitucionalizovaných vzt’ahov a známostí, inými

\footnotetext{
6 Toto rozlíšenie dvoch druhov kapitálu autori nechápu ako náhradu, ale skôr ako doplnenie iných klasifikácií sociálneho kapitálu, ktoré sa už stali súčastou terminologickej výbavy sociológie, ako je napríklad R. Putnamom zavedené a všeobecne používané rozlišovanie zväzujúceho (bonding) a premostujúceho (bridging) kapitálu, J. D. Lewandowskim zavedené rozlišovanie vertikálneho a horizontálneho kapitálu, doplnené ešte termínom spájajúci (linking) sociálny kapitál, označujúcom kontakty s osobami zastávajúcimi mocenské pozície atd'. (Putnam 2000; Lewandowski 2006; Grootaert 2004). Na základe toho Pichler a Wallace popri vlastnej klasifikácii bežne využivajú aj iné typológie sociálneho kapitálu.
} 
slovami z členstva v skupine, ktoré vybavuje každého jej člena kolektívne vlastneným kapitálom, čiže rôznymi oprávneniami“ (Bourdieu 1986: 248).

Spomedzi nemnohých autorov, ktorí do svojho skúmania sociálneho kapitálu zahrnuli aj otázku vzt’ahu sociálneho kapitálu a tried, patria napríklad N. Lin, P. A. Hall a okrajovo či nepriamo aj M. Granovetter, R. Putnam a iní. Predovšetkým Nan Lin sa pomerne výrazne inšpiroval aj týmto aspektom Bourdieuho diela, zasadil ho však do svojho prístupu k problematike, ktorému dominuje skúmanie sociálnych sietí vytváraných jednotlivcami a prístup teórie racionálnej vol'by. Podl'a neho aktér investuje do sociálneho kapitálu s ciel'om zlepšovat' si sociálnu pozíciu a minimalizovat' možné straty. Súčasne si však uvedomuje, že sociálny kapitál je vsadený v sociálnych štruktúrach, ktoré determinujú zdroje obsiahnuté $\mathrm{v}$ sociálnych siet’ach i pravidlá, ktorými sa riadia ich účastníci. Jednotlivé sociálne vrstvy, najmä tie najvyššie postavené, sa snažia prostredníctvom svojich sociálnych sietí monopolizovat' si spoločensky cenené zdroje. Sociálne siete najvyšších vrstiev sú preto podla neho uzavretejšie, hustejšie a silnejšie ako siete ostatných vrstiev (Lin 2001a,b). Sociálny kapitál jednotlivých vrstiev ovplyvňuje celkový tvar sociálnej stratifikácie, vel'kost' a charakteristiky jednotlivých vrstiev, ich sociálny odstup i d'alšie skutočnosti. N. Lin teda chápe sociálny kapitál ako činitel' vytvárajúci základ sociálnych nerovností: „Nerovnosti v sociálnom kapitáli sú explanačným rámcom nerovností v sociálnej stratifikácii“ (Lin 2001b: 96).

V súvislosti s využívaním prístupu metodologického individualizmu a racionálnej vol'by pri skúmaní vzt’ahu medzi triedami a sociálnym kapitálom viacerí autori kriticky poukázali na skutočnost', že zdôrazňovaním individualistickej stránky sociálneho kapitálu (najmä vyzdvihovaním investovania do sociálnych sietí) analytici sociálnych sietí zanedbávajú skúmanie spôsobov, ktorými sociálne siete (rovnako ako sociálny kapitál) pôsobia v sociálnych skupinách, teda i v triedach ako súčasti sociálnej štruktúry. Rovnako kritizovali aj to, že tento prístup často chápe sociálny kapitál iba ako majetok jednotlivcov, a nie ako zdroj vyplývajúci zo vzt’ahov medzi l'ud'mi (Edwards - Foley 1997; Somers 2005).

Spomedzi d'alších autorov, ktorí sa venovali teoreticko-empirickému skúmaniu vzt'ahu spoločenských tried a sociálneho kapitálu, možno spomenút' napríklad P. A. Halla. Vo svojom skúmaní sa zameral predovšetkým na súvislosti medzi triedami a sociálnymi siet’ami vo Vel'kej Británii a zistil, že stredné triedy tam charakterizujú širšie a rôznorodejšie sociálne siete (presahujúce aj do ostatných tried), ktoré sú vytvorené na základe bohatého spektra spoločenských činností príslušníkov týchto tried a ich združovania sa v množstve občianskych organizácií. Sociálne siete robotníckej triedy sú užšie, spravidla zahíňajú iba príslušníkov tejto triedy a sú vytvorené na základe obmedzeného počtu spoločných činností a občianskych združení vytváraných zväčša iba pre 
členov tejto triedy. Na základe týchto zistení teda možno tvrdit', že zatial' čo pre robotnícku triedu vo Vel'kej Británii je typický skôr zväzujúci kapitál, tamojšie stredné triedy sú charakteristické väčšou mierou premostujúceho kapitálu (Hall 1999, 2002). Aj F. Pichler a C. Wallace s využitím empirických údajov z 27 štátov Európskej únie zistili, že v prípade týchto spoločností možno vo všeobecnosti vyslovit' záver o vyššej miere sociálneho kapitálu u vyšších sociálnych tried, najmä pokial' ide o mieru združovania sa ich príslušníkov v občianskych organizáciách. Pokial' ide o rozsah, hustotu, silu a d’alšie charakteristiky sociálnych sietí, medzi jednotlivými spoločenskými triedami skúmaných európskych štátov nezistili významné rozdiely. V štátoch s výraznejšími rozdielmi a väšším odstupom medzi jednotlivými sociálnymi triedami boli aj rozdiely v objeme sociálneho kapitálu jednotlivých tried väčšie vzory sociálneho kapitálu teda zodpovedajú podobe systému stratifikácie spoločností (Pichler - Wallace 2007, 2008).

Títo autori na základe uvedených empirických poznatkov i teoretických záverov tvrdia, že vzt’ahu sociálnych tried a sociálneho kapitálu nemožno porozumiet' bez zohl'adnenia úlohy sociálnych sietí pri jeho vytváraní. Mnohí teoretici, najmä analytici sociálnych sietí sa pritom domnievajú, že to nemožno dosiahnut' s využitím údajov reprezentatívnych kvantitatívnych výskumov uskutočnených na vel'kých vzorkách, a preferujú analýzu sociálnych sietí v malých skupinách, skúmanie sociálneho kapitálu na mikroúrovni, využívanie prípadových štúdií a pod. Takéto prístupy však nemôžu priniest' všeobecné poznatky o tom, kol'ko a aké druhy sociálneho kapitálu majú rôzne sociálne skupiny, napríklad triedy, a nedokážu ani priniest' poznatky o vzt'ahu sociálneho kapitálu týchto skupín ku komplexným spoločenským makroštruktúram. Podl'a mnohých autorov aj napriek tomu, že sociálny kapitál vyjadruje najmä vzt’ahy medzi jednotlivcami na mikroúrovni spoločenského života, možno ho identifikovat', operacionalizovat' a merat' i na základe zistení kvantitatívnych výskumov realizovaných na reprezentatívnych vzorkách populácií štátov. Zdôrazňujú, že najväčším prínosom pritom môžu byt' zistenia takýchto výskumov o aktivitách jednotlivcov uskutočňovaných v rámci ich sociálnych sietí a tiež v ich dobrovol'ných občianskych združeniach. Hoci na základe tohto prístupu nemožno preskúmat' a objasnit' všetky dôležité aspekty problematiky vzt’ahu tried a sociálneho kapitálu a pôsobenia sociálneho kapitálu v stratifikačnom systéme, umožňuje preskúmat' aspoň niektoré základné súvislosti a vzt'ahy vypovedajúce o tejto oblasti života spoločností (Pichler - Wallace 2008: 320-321).

Empirické zistenia i teoretické analýzy uvedených i mnohých d’alších autorov teda potvrdzujú, že sociálny kapitál zahŕňa dimenziu šírky i dimenziu híbky sociálnych väzieb, interakcií a sietí spájajúcich jednotlivcov a sociálne skupiny. Preskúmanie sociálneho kapitálu si teda podl'a nich vyžaduje poznat' 
rozsah (extenzitu) formálnych i neformálnych sociálnych väzieb a sietí i frekvenciu (intenzitu) interakcií ich aktérov. Poznatky reprezentatívnych kvantitatívnych výskumov, ktoré zist'ujú členstvo respondentov v rôznych dobrovol'ných združeniach i mieru ich participácie v nich, nám umožňujú preskúmat' rozsah zapojenia sa l'udí do formálnych sociálnych sietí. Rozsah týchto sietí vypovedá o možnostiach jednotlivcov, ktorí sú do nich zapojení, využit' ich na získavanie rôznych zdrojov. Možno predpokladat', že čím rozsiahlejšie a rôznorodejšie je začlenenie jednotlivca do občianskych združení a organizácií, tým väčší potenciál získavania zdrojov pre neho predstavujú. Podobne sa možno domnievat', že čím väššieho počtu občianskych združení je jednotlivec členom a čím väššou mierou participuje na ich činnosti, tým širšiu, rôznorodejšiu a silnejšiu siet' neformálnych kontaktov, vzt'ahov a začlenení si takto vytvorí. Väčšia miera, resp. šírka takéhoto zapojenia i väčšia miera participácie teda s vysokou pravdepodobnost'ou znamenajú väčšiu šírku i híbku sociálnych interakcií, väzieb a sietí, čiže viac sociálneho kapitálu (Pichler - Wallace 2008: 321).

Treba mat' pritom stále na pamäti, že sociálny kapitál vcelku nemožno úplne identifikovat', operacionalizovat' a zmerat' a že is využitím naznačeného prístupu možno preskúmat' iba niektoré jeho aspekty - rovnako ako v prípade využitia iných metód analýzy sociálnych sietí. Reprezentatívne výskumy populácie však umožňujú prekonat' obmedzenia siet’ovej analýzy (limitovanej mikroúrovňou jej záberu) tým, že poskytujú údaje o zapojení sa jednotlivcov do sociálnych sietí a dobrovol'ných združení na reprezentatívnej, celospoločenskej úrovni, ktoré umožňujú formuláciu zovšeobecňujúcich záverov. Na základe zistení reprezentatívnych výskumov teda možno opísat' distribúciu sociálneho kapitálu v spoločnosti, napríklad medzi jednotlivými spoločenskými triedami a tiež podrobnejšie charakterizovat' sociálny kapitál jednotlivých tried, čo bežná analýza sociálnych sietí neumožňuje.

Aj v našom skúmaní vzt’ahu sociálneho kapitálu (ktorým rozumieme súhrn sociálnych väzieb a sietí jednotlivca, vsadených v sociálnej štruktúre a predstavujúcich reálne či potenciálne zdroje, ktoré môže využívat' vo svoj prospech) a spoločenských tried sa preto zameriame na preskúmanie šírky (extenzity) a hĺbky (intenzity) sociálnych väzieb a sietí jednotlivcov. Podobne ako F. Pichler a C. Wallace budeme pritom rozlišovat' dva druhy sociálneho kapitálu: kapitál vo formálnych a neformálnych sociálnych väzbách a siet’ach. Formálny kapitál budeme merat' na základe zapojenia sa l’udí do formálnych väzieb a vzt’ahov - do občianskych združení a organizácií a neformálny kapitál na základe ich zapojenia sa do neformálnych sociálnych sietí. Sociálne siete pritom budeme operacionalizovat' a merat' z hl'adiska ich šírky i hĺbky (extenzity aj intenzity). Šírku formálnych väzieb a sietí budeme chápat' a merat' ako počet formálnych združení a organizácií, ktorých členmi sú jednotlivci, híbku týchto 
sietí budeme merat' ako frekvenciu participácie l'udí na činnosti týchto organizácií. Šírku neformálnych väzieb a sociálnych sietí budeme merat' ako počet neformálnych kontaktov jednotlivcov a híbku týchto sietí budeme merat' ako silu ich väzieb s inými účastníkmi neformálnych sociálnych sietí, ktorých súčast'ou sú.

Ak vychádzame zo stanoviska triednej homológie, možno predpokladat', že nerovnosti l’udí v sociálnom kapitáli zodpovedajú ich rôznemu sociálnotriednemu postaveniu. Napríklad P. Bourdieu tvrdil, že sociálno-triedne postavenie ovplyvňuje objem a zloženie sociálneho kapitálu. Na základe toho možno predpokladat' existenciu súvislosti, prípadne i závislosti medzi spoločenskou triedou a formálnym i neformálnym sociálnym kapitálom osôb členstvo aj miera participácie na činnosti formálnych občianskych združení, ako aj rozsah a sila neformálnych sociálnych kontaktov ludí závisia od ich pozície v systéme stratifikácie, čiže od ich príslušnosti k určitej sociálnej triede. Príslušníci jednotlivých tried by sa na základe tohto stanoviska teda mali líšit' z hl'adiska svojho formálneho i neformálneho kapitálu. Ak vychádzame z opačného stanoviska, možno predpokladat', že rozdiely v šírke i híbke formálneho aj neformálneho kapitálu jednotlivcov nezodpovedajú vo významnej miere ich rôznemu sociálno-triednemu postaveniu, ale súvisia skôr s ich individuálnymi charakteristikami, ako sú vek, pohlavie, typ bydliska (vzdelanie je obsiahnuté v sociálno-triednom postavení). Tieto dve protikladné stanoviská sme otestovali na základe údajov získaných empirickým výskumom s ciel’om charakterizovat' základný vzt'ah medzi sociálnou triedou a sociálnym kapitálom v súčasnej slovenskej spoločnosti.

\section{Použité údaje a metodika výskumného postupu}

Pri našom testovaní platnosti dvoch možných (protikladných) vysvetlení vzt’ahu medzi spoločenskou triedou a sociálnym kapitálom sme vychádzali z údajov získaných medzinárodným empirickým výskumom ISSP, modul Sociálne siete $2017^{7}$, ktorý uskutočnila v októbri a novembri 2017 agentúra MEDIAN SK, s.r.o. na reprezentatívnej vzorke 1404 respondentov vybraných metódou kvótového výberu, technikou štandardizovaného rozhovoru na základe dotazníka vytvoreného riešitel'mi tejto výskumnej úlohy.

$\mathrm{Na}$ základe výskumom získaných údajov o zamestnaní, pracovnom postavení a riadiacej pozícii respondenta možno vytvorit' sociálno-triedne klasifikácie EGP, ESeC i ESeG a určit' v nich triednu pozíciu respondenta. Výskum zist'oval aj základné sociálno-demografické údaje respondentov: pohlavie, vek a vel'kost' bydliska, ktoré možno využit' na vytvorenie individuál-

\footnotetext{
7 Sociologický ústav SAV. ISSP Sociálne siete Slovensko 2017. [dátový súbor]. Slovenský archív sociálnych dát, 2018. SASD2017001. Verzia 1.0.
} 
nej charakteristiky respondenta. Výskumom získané dáta umožňujú na základe batérií otázok indikujúcich šírku (extenzitu) a hĺbku (intenzitu) participácie respondenta na formálnych občianskych združeniach aj neformálnych sociálnych sietach identifikovat' formálny i neformálny sociálny kapitál respondenta. Závislost' formálneho a neformálneho kapitálu od nezávislých premenných (sociálno-triedna príslušnost' a sociálno-demografické charakteristiky respondentov) možno testovat's použitím poradovej regresnej analýzy.

Pre potreby nášho testovania platnosti vzt’ahu medzi spoločenskou triedou a sociálnym kapitálom sme ako nezávislú premennú použili pozíciu respondenta $\mathrm{v}$ triednej klasifikácii ESeC (European socio-economic classification). Pri testovaní vzt’ahu medzi individuálnymi charakteristikami l’udí a sociálnym kapitálom sme ako nezávislé premenné použili pohlavie, vek a vel'kost' bydliska respondenta.

Použit' Európsku sociálno-ekonomicku klasifikáciu sme sa rozhodli preto, lebo na základe testovania kriteriálnej a konštruktovej validity v podmienkach slovenskej spoločnosti sa ukázala ako najvalídnejšia spomedzi najpoužívanejších sociálno-triednych klasifikácií EGP, ESeC a ESeG (Bunčák - Hrabovská Sopóci 2018) a osvedčila sa i ako východisko pre analýzu sociálnej mobility na Slovensku (Džambazovič - Gerbery 2018). Európska sociálno-ekonomická klasifikácia je triedna klasifikácia vytvorená pre potreby opisu a komparácie zamestnaneckých a stratifikačných štruktúr v štátoch Európskej únie (Rose Harrison 2010). Rovnako ako časovo ju predchádzajúca Goldthorpeho triedna klasifikácia EGP, aj ESeC teoreticky vychádza zo štruktúry pozícií na trhu práce, čiže zo štruktúry zamestnaní, ktoré sú $\mathrm{v}$ oboch prípadoch považované za základ sociálnej stratifikácie. Zoskupenia pozícií na trhu práce sú teda i v tejto klasifikácii východiskom vymedzenia sociálnych tried, pričom postavenie týchto tried v klasifikácii ESeC je určené najmä na základe vzájomného vzt’ahu zamestnaneckých pozícií. Rovnako ako Goldthorpeho triedna schéma, aj klasifikácia $\mathrm{ESeC}$ rozlišuje zamestnávatel'ov, samostatne zárobkovo činných a zamestnancov, pridáva $\mathrm{k}$ nim však kategóriu exkludovaných, zahŕňajúcu l'udí nedobrovol’ne vylúčených z trhu práce (dlhodobo nezamestnaných) a ludí, ktorí ešte nepracovali (študenti, osoby v domácnosti). Popri pozícii na trhu práce sa $\mathrm{v}$ tejto klasifikácii uplatňujú ako d’alšie kritériá členenia: výška vzdelania a stupeň kvalifikácie pre prácu, participácia na riadení a kontrola v práci, vel'kost' firmy meraná počtom zamestnancov a tiež odvetvie, v ktorom zamestnávatelia, samozamestnávatelia i zamestnanci pôsobia.

Úplná klasifikácia ESeC sa skladá z desiatich kvalitatívne odlišných tried, ktoré sú označované arabskými číslicami (tabul'ka č. 1). Táto klasifikácia nemá hierarchický charakter, jej autori však pripúšt’ajú, že triedy 1 a 2 sú na základe výšky a zaistenia príjmu umiestnené vyššie ako triedy 3, 6, 7, 8, 9 (Rose Harrison - Pevalin 2010). Pri našom testovaní sme použili trojtriednu verziu

Sociológia 51, 2019, č. 5 
klasifikácie $\mathrm{ESeC}$, pričom vytvorené tri základné sociálne triedy budeme d’alej označovat' ako vyššie, stredné a nižšie triedy ${ }^{8}$.

\section{Tabul'ka č. 1: Triedna klasifikácia ESeC}

\begin{tabular}{|c|c|c|c|}
\hline Č. & Názov triedy & Špecifikácia & Trojtriedna verzia \\
\hline 1 & Vyšší salariát & $\begin{array}{l}\text { Vel'kí zamestnávatelia, vysoko kvalifikované } \\
\text { odborné administratívne a manažérske } \\
\text { zamestnania }\end{array}$ & $1+2$ \\
\hline 2 & Nižší salariát & $\begin{array}{l}\text { Odborné, administratívne, technické } \\
\text { a manažérske zamestnania so stredoškolskou } \\
\text { kvalifikáciou }\end{array}$ & \\
\hline 3 & $\begin{array}{l}\text { Biele goliere } \\
\text { vyššieho stupňa }\end{array}$ & Medzil'ahlé zamestnania & $3+4+5+6$ \\
\hline 4 & $\begin{array}{l}\text { Drobná buržoázia } \\
\text { alebo nezávislí }\end{array}$ & $\begin{array}{l}\text { Drobní zamestnávatelia a súkromní } \\
\text { podnikatelia mimo pol'nohospodárstva }\end{array}$ & \\
\hline 5 & $\begin{array}{l}\text { Drobná buržoázia a } \\
\text { lebo nezávislí }\end{array}$ & $\begin{array}{l}\text { Samozamestnávatelia a súkromní podnikatelia } \\
\text { v pol'nohospodárstve }\end{array}$ & \\
\hline 6 & $\begin{array}{l}\text { Modré goliere } \\
\text { vyššieho stupňa }\end{array}$ & Nižšie riadiace a technické zamestnania & \\
\hline 7 & $\begin{array}{l}\text { Biele goliere } \\
\text { nižšieho stupňa }\end{array}$ & $\begin{array}{l}\text { Nižšie zamestnania v službách, obchode, } \\
\text { administratíve }\end{array}$ & $7+8+9$ \\
\hline 8 & $\begin{array}{l}\text { Kvalifikovaní manuálni } \\
\text { Pracovníci }\end{array}$ & Nižšie technické zamestnania & \\
\hline 9 & $\begin{array}{l}\text { Polokvalifikovaní } \\
\text { a nekvalifikovaní manuálni } \\
\text { pracovníci }\end{array}$ & Rutinné zamestnania & \\
\hline 10 & $\begin{array}{l}\text { Nikdy nepracujúci a dlhodobo } \\
\text { nezamestnaní }\end{array}$ & Nikdy nepracujúci a dlhodobo nezamestnaní & $(10)$ \\
\hline
\end{tabular}

Zdroj: Rose - Harrison - Pevalin 2010: 13, 21

Ako závislé premenné sme pri analýze použili šírku a hĺbku formálneho i neformálneho sociálneho kapitálu, ktoré boli vo výskume Sociálne siete 2017 zist'ované prostredníctvom viacerých otázok. Spomedzi nich sa dali použit' iba otázky, ktoré sa zameriavali na zist'ovanie sociálnych činností a sociálnych kontaktov respondentov. Otázky zist'ujúce hodnotenia a názory respondentov, alebo nimi preferované spôsoby konania $\mathrm{v}$ hypotetických situáciách neboli použitel'né ${ }^{9}$. Śírku a híbku formálneho kapitálu výskum zist'oval prostredníctvom otázky merajúcej rozsah a intenzitu účasti respondenta na činnosti vybraných druhov formálnych združení ${ }^{10}$. Šírku účasti predstavuje účast' na

\footnotetext{
8 Ich zastúpenie vo výberovom súbore bolo: vyššie triedy $24 \%$, stredné triedy $21 \%$, nižšie triedy $55 \%$.

9 Dôvodom bola najčastejšie nevhodná, sociologicky chybná formulácia otázok medzinárodného dotazníka výskumu ISSP Sociálne siete 2017, ktorej dôsledkom bola atypická a štatisticky nespracovatel’ná distribúcia odpovedí respondentov.

10 Znenie otázky:

Ako často ste sa za posledných 12 mesiacov zúčastnili činností ... ? vo vol'nočasových, športových alebo kultúrnych združeniach,
} 
činnosti žiadneho, jedného, dvoch, alebo všetkých troch druhov združení uvedených v otázke. Híbku, resp. intenzitu participácie vyjadruje suma bodovej hodnoty pridelenej jednotlivým variantom odpovedí vyjadrujúcim frekvenciu účasti na činnosti uvedených troch druhov združení.

Šírku a hĺbku neformálneho kapitálu výskum meral prostredníctvom otázky zist'ujúcej rozsah a intenzitu (silu) vybraných druhov neformálnych sociálnych kontaktov respondenta ${ }^{11}$. Śŕrku neformálnych sociálnych kontaktov ${ }^{12}$ predstavuje počet povolaní z uvedeného zoznamu, vykonávatel'ov ktorých respondent pozná. Silu neformálnych kontaktov vyjadrujú varianty: existencia príbuzného, ktorý vykonáva zamestnanie zo zoznamu, existencia takéhoto blízkeho kamaráta, resp. známeho, existencia inej známej osoby, ktorá vykonáva niektoré zamestnanie zo zoznamu a neexistencia nikoho takého spomedzi respondentových príbuzných, priatel'ov a známych. Varianty odpovedí, ktoré vyjadrujú blízkost' osoby vykonávajúcej zamestnanie zo zoznamu respondentovi, majú pridelené bodové hodnoty. Intenzitu neformálnych kontaktov respondenta potom vyjadruje suma bodov získaných za všetkých respondentom uvedených vykonávatel'ov povolaní z predloženého zoznamu.

Pri analýze súvislostí medzi jednotlivými druhmi kapitálu sme najskôr preskúmali vzt’ahy medzi extenzitou a intenzitou formálnych i neformálnych kontaktov, ako aj vzt'ahy medzi formálnym a neformálnym kapitálom u respondentov výskumu. Potom sme bližšie charakterizovali tri základné spoločenské triedy klasifikácie ESeC z hl’adiska ich sociálneho kapitálu. Nakoniec sme preskúmali závislosti formálneho a neformálneho kapitálu od nezávislých premenných: s využitím poradovej regresnej analýzy (metóda logit) sme

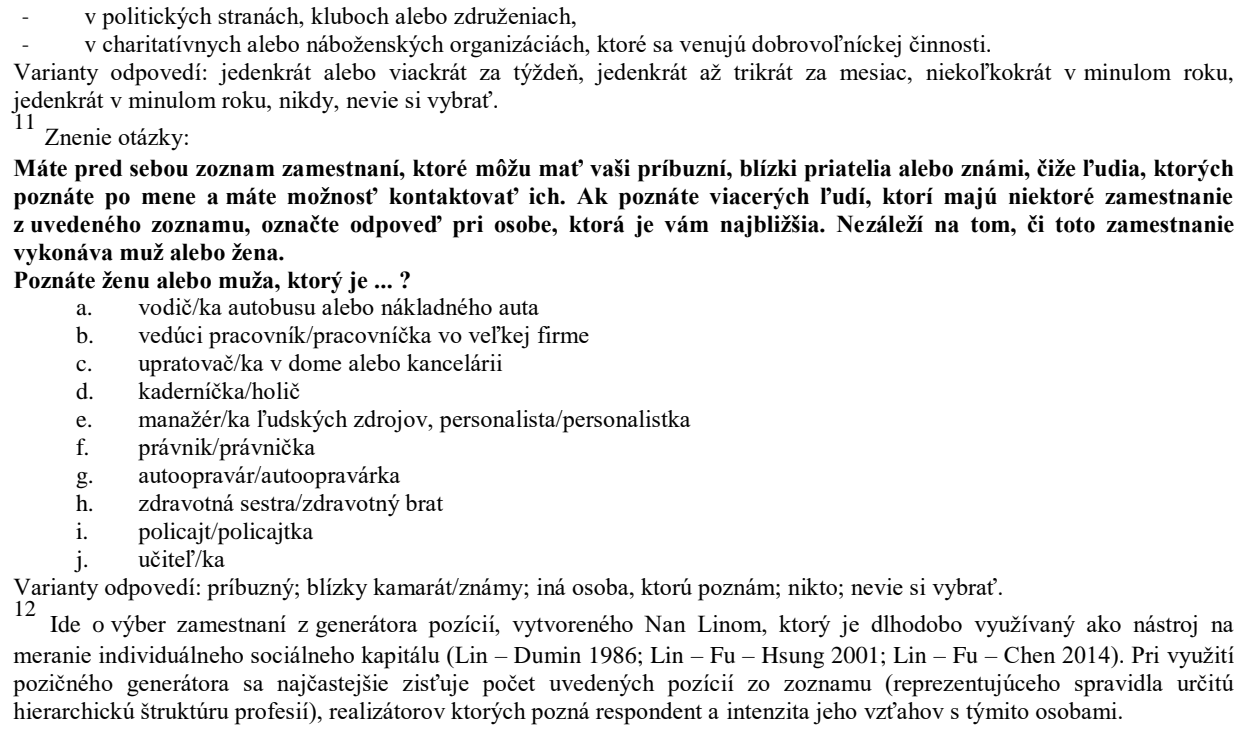

12 Ide o výber zamestnaní z generátora pozícií, vytvoreného Nan Linom, ktorý je dlhodobo využívaný ako nástroj na meranie individuálneho sociálneho kapitálu (Lin - Dumin 1986; Lin - Fu - Hsung 2001; Lin - Fu - Chen 2014). Pri využití pozičného generátora sa najčastejšie zist'uje počet uvedených pozícií zo zoznamu (reprezentujúceho spravidla určitú hierarchickú štruktúru profesií), realizátorov ktorých pozná respondent a intenzita jeho vzt’ahov s týmito osobami. 
zist'ovali, ktoré nezávislé premenné ovplyvňujú jednotlivé indikátory formálneho a neformálneho sociálneho kapitálu.

\section{Sociálny kapitál základných spoločenských tried}

Skôr než pristúpime k analýze vzt'ahov medzi sociálnym kapitálom a spoločenskými triedami, uvedieme základné zistenia výskumu o celkovej šírke a híbke (extenzite a intenzite) formálneho i neformálneho kapitálu. Tieto nám umožňujú konštatovat', že na základe použitých ukazovatel'ov sa potvrdil predpoklad o vysokej miere súvislosti medzi týmito dvomi dimenziami formálneho i neformálneho kapitálu a zistila sa tiež vysoká miera súvislosti medzi formálnym a neformálnym kapitálom.

Údaje zhrnuté v tabul'ke č. 2 ukazujú celkovú menšiu, resp. podpriemernú šírku formálneho kapitálu respondentov výskumu, ktorí počas minulých 12 mesiacov v priemere participovali na činnosti iba jedného $\mathrm{z}$ troch možných druhov dobrovol'ných občianskych združení, resp. organizácií. Občan sa teda $\mathrm{v}$ priemere zapojil do aktivít aspoň jedného $\mathrm{z}$ troch zist'ovaných druhov združení, pričom na jeho činnosti sa podiel'al zväčša niekol'kokrát v priebehu roka. Aj priemerná intenzita participácie občanov na činnosti dobrovol'ných združení a organizácií bola teda nízka.

Pokial' ide o neformálny kapitál, respondenti výskumu majú v priemere kontakty s osobami vykonávajúcimi až dve tretiny zo zamestnaní obsiahnutých v predloženom zozname, čo predstavuje nadpriemerne široké siete známostí a kontaktov. Zistená priemerná hodnota intenzity, resp. sily týchto kontaktov pritom vypovedá, že $\mathrm{v}$ skladbe týchto neformálnych sietí respondentov prevládajú tzv. slabé väzby, čiže známosti a kontakty s kamarátmi, s blízkymi i vzdialenejšími známymi.

Tabul'ka č. 2: Priemerná extenzita a intenzita formálneho a neformálneho kapitálu

\begin{tabular}{lccccc}
\hline $\begin{array}{l}\text { Druh sociálneho kapitálu, } \\
\text { dimenzia }\end{array}$ & $\begin{array}{c}\text { Minimálna } \\
\text { hodnota }\end{array}$ & $\begin{array}{c}\text { Maximálna } \\
\text { hodnota }\end{array}$ & $\begin{array}{c}\text { Priemerná } \\
\text { hodnota }\end{array}$ & $\begin{array}{c}\text { Smerodajná } \\
\text { odchýlka }\end{array}$ & N \\
\hline Formálny, extenzita & 0 & 3 & 1,29 & 1,096 & 1393 \\
Formálny, intenzita & 0 & 12 & 2,98 & 2,749 & 1393 \\
Neformálny, extenzita & 0 & 10 & 6,78 & 2,848 & 1378 \\
Neformálny, intenzita & 0 & 30 & 12,12 & 5,679 & 1378 \\
\hline
\end{tabular}

Pri skúmaní vzt’ahu medzi dvomi vymedzenými dimenziami možno na základe zistení výskumu konštatovat' vysokú mieru súvislosti medzi extenzitou a intenzitou formálneho i neformálneho kapitálu (hodnoty koeficientov korelácie: 0,878 a 0,863). Znamená to, že l'udia, ktorí sú členmi viacerých 
druhov dobrovol’ných občianskych organizácií, participujú na ich činnosti intenzívnejšie ako l'udia, ktorí sú iba členmi jednej takejto organizácie ${ }^{13}$. Podobne, l'udia, ktorí majú známych vykonávajúcich väčší počet rôznych zamestnaní, majú medzi nimi väčší podiel osôb, ktorí sú ich príbuznými, blízkymi priatel'mi a známymi než l'udia, ktorí majú známych vykonávajúcich menší počet zamestnaní z predloženého zoznamu.

Zistenia výskumu d’alej ukazujú, že i medzi formálnym a neformálnym kapitálom existuje pomerne vysoká miera súvislosti (hodnoty koeficientov: 0,335 v prípade extenzity a 0,330 v prípade intenzity). Ukázalo sa teda, že l'udia, ktorí sú členmi a aktívnymi participantmi viacerých druhov občianskych združení, majú širší a z hl'adiska vykonávaných zamestnaní rôznorodejší okruh známych ako l'udia, ktorí sú občiansky menej aktívni, resp. pasívni. Možno teda konštatovat': výskum potvrdil predpoklad, že l'udia, ktorí sú aktívnejší v oblasti občianskeho združovania, majú väčší okruh známych z rôznych oblastí profesionálneho života. Túto súvislost' možno pritom vyjadrit' aj tak, že l'udia s väčším počtom (a profesijne rôznorodých) známych sú častejšie členmi rôznych občianskych združení ako l’udia, ktorí majú známych málo, prípadne sú takto sociálne izolovaní.

$\mathrm{Na}$ základe uvedených skutočností teda možno konštatovat', že formálny a neformálny kapitál navzájom súvisia, resp. sa i podmieňujú, pričom ide o pomerne silnú súvislost'. Tento poznatok nás oprávňuje d’alej analyzovat' zistenia výskumu o formálnom a neformálnom kapitáli oddelene, ale aj v ich vzájomnom vzt’ahu a vich celku ${ }^{14}$. Pri analýze vzt’ahov medzi sociálnym kapitálom a spoločenskými triedami, resp. sociálno-triednou pozíciou (a na druhej strane medzi sociálnym kapitálom a individuálnymi charakteristikami osôb) budeme teda postupovat' tak, že najskôr preskúmame jednotlivé triedy z hl'adiska ich vzorov, resp. zastúpenia a zloženia ich formálneho i neformálneho kapitálu. Paralelne s tým preskúmame i vzory formálneho a neformálneho kapitálu u základných vekových, rodových a sídelných kategórií respondentov výskumu. Na záver otestujeme vzt’ah medzi triednou príslušnost'ou, individuálnymi charakteristikami a sociálnym kapitálom, čiže predpoklad o rôznej miere súvislosti medzi sociálno-triednymi a individuálnymi charakteristikami ludí a ich sociálnym kapitálom.

$\mathrm{Na}$ základe rozboru extenzity a intenzity formálneho i neformálneho kapitálu troch základných tried klasifikácie ESeC možno konštatovat', že aj u nás sú jednotlivé spoločenské triedy charakteristické rôznou mierou týchto

\footnotetext{
13 Participácia osôb na činnosti občianskych organizácií, ktorej členmi nie sú, je zrejme ešte zriedkavejšia, hoci nie je vylúčená - ako napríklad v prípade tzv. nezávislých politikov kandidujúcich za politické strany.

14 Pre d’alšie analýzy sme z pôvodných hodnôt extenzity a intenzity formálneho i neformálneho sociálneho kapitálu vytvorili štyri kategórie, od najnižšej po najvyššiu. S takto vytvorenými indikátormi sme d'alej pracovali ako s poradovými premennými.
} 
druhov kapitálu a tiež rôznou mierou oboch dimenzií formálneho i neformálneho kapitálu. Ako vyplýva $\mathrm{z} \operatorname{grafu}^{15}$ č. 1 , vyššie a stredné spoločenské triedy pritom disponujú väčším formálnym i neformálnym kapitálom ako nižšie triedy a to pokial' ide o šírku aj o híbku oboch druhov kapitálu. Zaujímavé pritom je, že zatial' čo v prípade formálneho kapitálu stredné triedy v miere extenzity aj intenzity prevyšujú vyššie triedy, v prípade neformálneho kapitálu je miera šírky i híbky oboch druhov kapitálu usporiadaná zostupne: od vyšších, cez stredné, až po nižšie triedy. Medzitriedne rozdiely vintenzite a extenzite formálneho kapitálu sú pritom výraznejšie ako v prípade neformálneho kapitálu.

\section{Graf č. 1: Formálny a neformálny kapitál základných sociálnych tried}

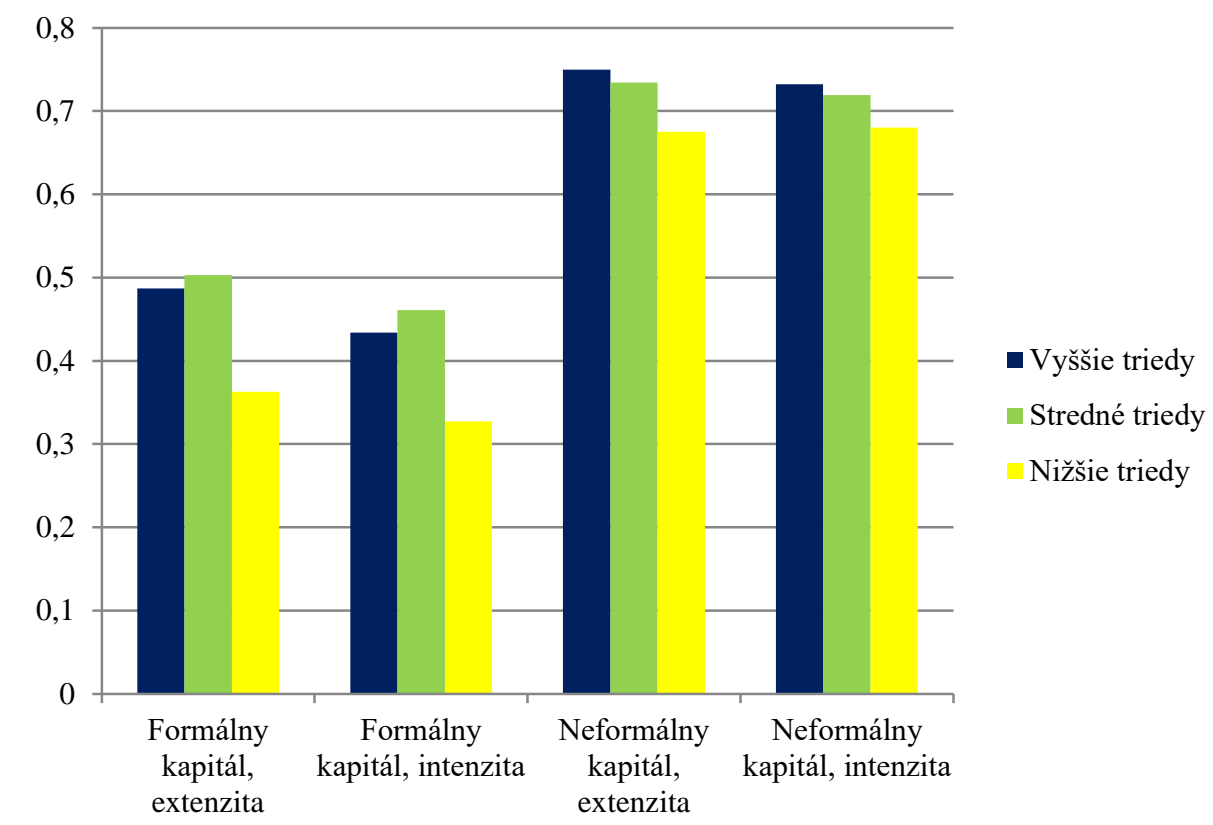

Zistenia výskumu teda ukázali, že príslušníci vyšších a stredných spoločenských tried sú i u nás spravidla členmi väčšieho počtu občianskych združení a organizácií rôzneho druhu ako členovia nižších tried a že tiež vo väčšej miere participujú na činnosti týchto združení. Podobne majú členovia vyšších a stredných tried širšie neformálne sociálne siete, teda väčší počet známych osôb vykonávajúcich rôzne zamestnania, ako príslušníci nižších tried. Pritom

\footnotetext{
15 Hodnoty extenzity a intenzity formálneho i neformálneho kapitálu boli vyrátané na základe uskutočnenej rekategorizácie pôvodných stupníc a priradenia bodových hodnôt jednotlivým variantom odpovedí na otázky tak, aby sa výsledné priemerné hodnoty meraných veličín pohybovali v intervale 0 až 1 . Podrobnosti možno získat' $z$ archívu autorov štúdie.
} 
medzi takýmito osobami je väčší podiel osôb, s ktorými ich spájajú tzv. silné väzby. Podobne ako v niektorých iných európskych štátoch (Hall 2002; Pichler - Wallace 2008), aj u nás sú teda vyššie a stredné triedy charakteristické širšími a rôznorodejšími neformálnymi sociálnymi sietami ako nižšie triedy, pričom tieto siete sú vytvorené na základe rozsiahlejšieho združovania sa a aktívnejšej participácie príslušníkov týchto tried na činnosti rôznych občianskych združení a organizácií.

Diferencovanost' týkajúcu sa extenzity a intenzity formálneho i neformálneho sociálneho kapitálu výskum zistil aj v súvislosti s individuálnymi charakteristikami respondentov - menšie či väčšie rozdiely sa ukázali aj medzi mužmi a ženami, medzi vekovými kategóriami i medzi obyvatel'mi miest a dedín. Údaje zhrnuté v tabul'ke č. 3 ukazujú, že muži u nás disponujú väčšou extenzitou aj intenzitou formálneho i neformálneho kapitálu ako ženy, l'udia vo veku od 25 do 45 rokov zväčša predstihujú zhl'adiska týchto skutočností ostatné vekové kohorty a obyvatelia vel'komiest a väčších miest disponujú väčšou extenzitou aj intenzitou formálneho i neformálneho kapitálu ako obyvatelia stredných a malých miest a dedín.

Tabul'ka č. 3: Formálny a neformálny kapitál vybraných kategórií respondentov

\begin{tabular}{lcccc}
\hline \multirow{2}{*}{ Kategórie respondentov } & \multicolumn{2}{c}{ Formálny kapitál } & \multicolumn{2}{c}{ Neformálny kapitál } \\
\cline { 2 - 5 } & extenzita & intenzita & extenzita & intenzita \\
\hline Muži & 0,447 & 0,433 & 0,726 & 0,709 \\
Ženy & 0,417 & 0,380 & 0,573 & 0,682 \\
Do 24 rokov & 0,607 & 0,540 & 0,664 & 0,659 \\
25 až 45-roční & 0,657 & 0,502 & 0762 & 0,745 \\
Nad 46 rokov & 0,572 & 0,377 & 0,748 & 0,717 \\
Obyvatelia vel'komiest a väčších miest & 0,680 & 0,558 & 0,728 & 0,718 \\
Obyvatelia stredných a malých miest & 0,547 & 0,360 & 0,693 & 0,688 \\
Obyvatelia dedín & 0,546 & 0,373 & 0,698 & 0,697 \\
\hline
\end{tabular}

Výsledky uskutočneného testovania vzt'ahu medzi triednou príslušnost'ou, individuálnymi charakteristikami a sociálnym kapitálom potvrdili predpoklad o rôznej miere súvislosti medzi sociálno-triednymi a individuálnymi charakteristikami l'udí a ich sociálnym kapitálom. Ukázalo sa, že extenzita aj intenzita formálneho i neformálneho sociálneho kapitálu súvisí so základnými sociálnymi triedami klasifikácie $\mathrm{ESeC}$, zároveň sa však ukázalo, že súvisí aj s niektorými individuálnymi charakteristikami, najmä s vekom, a v niektorých prípadoch i s druhom sídla a rodom osôb. Zatial' čo súvislost' medzi triednou príslušnost'ou a sociálnym kapitálom sa potvrdila v prípade oboch druhov kapitálu i v prípade oboch ich dimenzií, súvislost medzi individuálnymi 
charakteristikami osôb a sociálnym kapitálom sa javí skôr ako nesystematická. Na základe toho sa možno domnievat', že zistenia výskumu ISSP Sociálne siete 2017 na základe testovania vzt’ahu medzi spoločenskými triedami a sociálnym kapitálom potvrdili skôr stanovisko triednej homológie ako individualistické stanovisko.

Konkrétnejšie informácie o výsledkoch uskutočneného testovania obsahuje tabul'ka č. 4, obsahujúca výsledky poradovej regresie so závislými premennými extenzita a intenzita formálneho a neformálneho kapitálu.

\section{Tabul'ka č. 4: Výsledky poradovej regresie}

Poradová regresia so závislou premennou extenzita formálneho kapitálu

\begin{tabular}{|c|c|c|}
\hline Nezávislé premenné & Koeficient & Významnost' \\
\hline Trieda $\mathrm{ESeC}=$ Vyššie triedy & ,413 & ,003 \\
\hline Trieda $\mathrm{ESeC}=$ Stredné triedy & ,367 & ,011 \\
\hline \multicolumn{3}{|l|}{ Trieda $\mathrm{ESeC}=$ Nižšie triedy (ref. kategória) } \\
\hline Pohlavie $=$ Muž & ,072 & ,518 \\
\hline \multicolumn{3}{|l|}{ Pohlavie = Žena (ref. kategória) } \\
\hline Vek $=$ do 24 rokov & 1,783 & ,000 \\
\hline Vek $=25-45$ rokov & 1,416 &, 000 \\
\hline Vek $=46-59$ rokov & ,894 & ,000 \\
\hline \multicolumn{3}{|l|}{ Vek = 60 a viac rokov (ref. kategória) } \\
\hline Sídlo $=$ Väčšie mesto, predmestie & ,819 & ,000 \\
\hline Sídlo = Stredne vel'ké, menšie mesto & 012 & ,924 \\
\hline Sídlo = Dedina , farma. samota (ref. kategória) & & \\
\hline
\end{tabular}

Poradová regresia so závislou premennou intenzita formálneho kapitálu

\begin{tabular}{|c|c|c|}
\hline Nezávislé premenné & Koeficient & Významnost' \\
\hline Trieda $\mathrm{ESeC}=$ Vyššie triedy & ,397 & ,004 \\
\hline Trieda $\mathrm{ESeC}=$ Stredné triedy & ,370 & ,011 \\
\hline \multicolumn{3}{|l|}{ Trieda ESeC = Nižšie triedy (ref. kategória) } \\
\hline Pohlavie $=$ Muž & ,203 & 070 \\
\hline \multicolumn{3}{|l|}{ Pohlavie = Žena (ref. kategória) } \\
\hline Vek $=$ do 24 rokov & 1,637 &, 000 \\
\hline Vek $=25-45$ rokov & 1,580 & ,000 \\
\hline Vek $=46-59$ rokov & ,893 & ,000 \\
\hline \multicolumn{3}{|l|}{ Vek = 60 a viac rokov (ref. kategória) } \\
\hline Sídlo = Väčšie mesto, predmestie & ,938 &, 000 \\
\hline Sídlo = Stredne vel'ké, menšie mesto &,- 044 & ,726 \\
\hline Sídlo = Dedina, farma. samota (ref. kategória) & & \\
\hline
\end{tabular}


Poradová regresia so závislou premennou extenzita neformálneho kapitálu

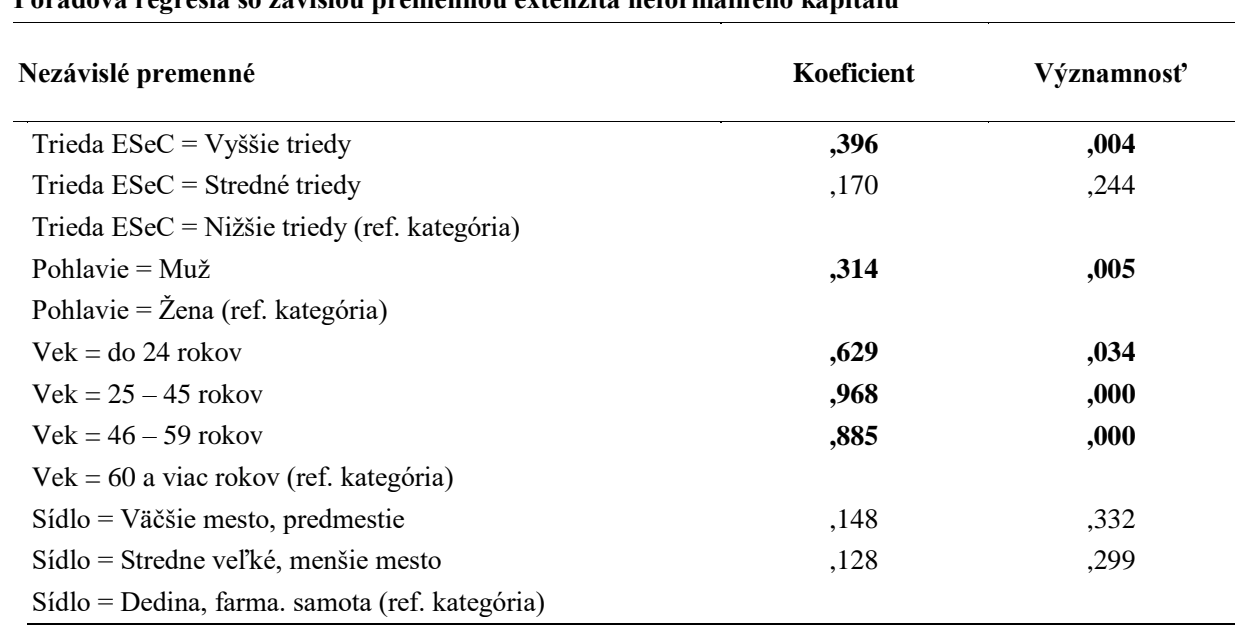

Poradová regresia so závislou premennou intenzita neformálneho kapitálu

\begin{tabular}{|c|c|c|}
\hline Nezávislé premenné & Koeficient & Významnost' \\
\hline Trieda $\mathrm{ESeC}=$ Vyššie triedy & 294 & ,033 \\
\hline Trieda $\mathrm{ESeC}=$ Stredné triedy & 142 & ,330 \\
\hline \multicolumn{3}{|l|}{ Trieda ESeC = Nižšie triedy (ref. kategória) } \\
\hline Pohlavie $=$ Muž & 212 & ,056 \\
\hline \multicolumn{3}{|l|}{ Pohlavie = Žena (ref. kategória) } \\
\hline Vek $=$ do 24 rokov & 452 & 128 \\
\hline Vek $=25-45$ rokov & ,667 &, 000 \\
\hline Vek $=46-59$ rokov &, 595 &, 000 \\
\hline \multicolumn{3}{|l|}{ Vek = 60 a viac rokov (ref. kategória) } \\
\hline Sídlo = Väčšie mesto, predmestie &,- 038 & ,800 \\
\hline Sídlo $=$ Stredne vel'ké, menšie mesto &,- 038 & ,758 \\
\hline Sídlo = Dedina, farma. samota (ref. kategória) & & \\
\hline
\end{tabular}

Z údajov v tabul'kách vyplýva, že extenzita formálneho kapitálu súvisí

- s vekom: extenzita formálneho kapitálu respondentov vo veku do 59 rokov je väčšia ako extenzita formálneho kapitálu respondentov vo vekovej skupine 60 a viac rokov,

- so základnými sociálnymi triedami ESeC: extenzita formálneho kapitálu respondentov z vyššej a strednej triedy je väčšia ako u respondentov z nižšej triedy,

- so sídlom: extenzita formálneho kapitálu respondentov žijúcich vo väčších mestách je väčšia ako extenzita formálneho kapitálu respondentov žijúcich na dedine. 
Podobne aj intenzita formálneho kapitálu súvisí

- s vekom: intenzita formálneho kapitálu respondentov vo veku do 59 rokov je väššia ako intenzita formálneho kapitálu respondentov vo vekovej skupine 60 a viac rokov,

- so základnými sociálnymi triedami ESeC: intenzita formálneho kapitálu respondentov $\mathrm{z}$ vyšších a stredných tried je väčšia ako u respondentov $\mathrm{z}$ nižších tried,

- so sídlom: intenzita formálneho kapitálu respondentov žijúcich vo väčších mestách je väčšia ako u respondentov žijúcich na dedine.

Extenzita neformálneho kapitálu súvisí

- s vekom: extenzita neformálneho kapitálu respondentov vo veku do 59 rokov je väčšia ako u respondentov vo vekovej skupine 60 a viac rokov,

- so sociálnymi triedami ESeC: extenzita neformálneho kapitálu respondentov z vyšších tried je väčšia ako u respondentov z nižších tried,

- s pohlavím, resp. rodom: extenzita neformálneho kapitálu mužov je väčšia ako u žien.

Intenzita neformálneho kapitálu súvisi

- s vekom: intenzita neformálneho kapitálu respondentov vo veku od 25 do 59 rokov je väčšia ako u respondentov vo vekovej skupine 60 a viac rokov,

- so základnými sociálnymi triedami ESeC: intenzita neformálneho kapitálu respondentov $\mathrm{z}$ vyšších tried je väčšia ako intenzita neformálneho kapitálu respondentov $\mathrm{z}$ nižších tried.

\section{Záver}

Výsledky našej analýzy teda ukazujú, že formálny i neformálny kapitál je v slovenskej spoločnosti sociálne stratifikovaný, pričom väčšie rozdiely medzi základnými sociálnymi triedami existujú $\mathrm{v}$ intenzite aj extenzite ich formálneho kapitálu - príslušníci vyšších a stredných sociálnych tried sú členmi väčšieho počtu formálnych občianskych združení a organizácií ako príslušníci nižších tried a aj miera ich participácie na činnosti týchto združení je vyššia ako miera participácie príslušníkov nižších tried. Medzitriedne rozdiely existujú i v miere intenzity a extenzity neformálneho kapitálu - príslušníci vyšších tried majú rozsiahlejšie a silnejšie siete neformálnych vzt’ahov ako príslušníci stredných tried, a tí majú rozsiahlejšie a silnejšie siete týchto vzt’ahov ako príslušníci nižších tried; tieto rozdiely sú však menšie ako v prípade formálneho kapitálu.

Výskumné zistenia tiež ukazujú, že formálny a neformálny kapitál základných sociálnych tried navzájom súvisia, resp. sa i podmieňujú, pričom ide o pomerne silnú súvislost'. Ludia, ktorí sú členmi a aktívnymi participantmi viacerých druhov občianskych združení, majú širší a z hl'adiska vykonávaných zamestnaní rôznorodejší okruh známych ako l'udia, ktorí sú menej občiansky aktívni. Inak vyjadrené: l’udia $\mathrm{s}$ väčším počtom profesijne rôznorodých 
známych sa častejšie zapájajú do činnosti občianskych združení ako l’udia, ktorí majú menej sociálnych kontaktov a väzieb. Vel'kost' a homogenita/heterogenita sociálnych sietí príslušníkov spoločenských tried teda súvisia s ich občianskou angažovanost'ou.

Teoreticko-metodologické východiská a z nich vyplývajúce limity výskumu, z ktorého sme vychádzali, nám dovolili verifikovat iba malú, hoci významnú čast' teórie, resp. koncepcie sociálneho kapitálu. Na základe uskutočnenej analýzy jeho zistení môžeme konštatovat', že vzt'ah medzi spoločenskými triedami a sociálnym kapitálom na Slovensku najlepšie charakterizuje stanovisko, resp. model triednej homológie. Testovanie d'alších súčasti teórie sociálneho kapitálu, napríklad podrobnejšie a dôkladnejšie charakterizovanie sociálneho kapitálu jednotlivých tried, $\mathrm{k}$ akému dospeli P. Hall alebo N. Lin (Hall 2002; Lin 2001a,b), či vzt’ahov medzi týmito charakteristikami a jednotlivými sociálnymi triedami, prípadne objasnenie spôsobov utvárania a reprodukcie sociálneho kapitálu tried a jeho využívania pri udržiavaní existujúceho alebo získavaní výhodnejšieho triedneho postavenia, ako v prípade analýz P. Bourdieuho (Bourdieu 1987; Bourdieu - Passeron 1977), výskum Sociálne siete 2017 neumožňuje. Dovol'uje iba (po dokončení spracovania a archivácii všetkých získaných údajov) uskutočnit' komparáciu základných zistení o sociálnom kapitáli a spoločenských triedach vo viacerých európskych aj iných štátoch, čo bude predmetom nášho d’alšieho skúmania. Napriek nedostatkom a obmedzeniam tohto výskumu treba vyzdvihnút', že ide o prvý u nás realizovaný kvantitatívny reprezentatívny výskum, ktorý umožňuje testovat' hypotézy o vzt'ahoch medzi spoločenskými triedami a sociálnym kapitálom, čo by na základe využitia klasickej analýzy sociálnych sietí (výskumu na mikroúrovni) nebolo možné.

Treba tiež zdôraznit' skutočnost', že východiskové chápanie sociálneho kapitálu a pri analýze použité rozlíšenie jeho dvoch druhov a ich dimenzií priniesli viaceré významné zistenia súvisiace s vytváraním a udržiavaním sociálneho kapitálu rôznych spoločenských skupín a kategórií obyvatel'stva. Ide najmä o zistenia týkajúce sa vzt’ahov medzi občianskym združovaním a aktívnou participáciou l'udí v dobrovol’ných organizáciách, medzi rozsahom a silou neformálnych sociálnych sietí a diferencovanou vel'kost'ou sociálneho kapitálu nielen spoločenských tried, ale i d’alších skupín a kategórií nášho obyvatel'stva. Aj tieto základné zistenia o vzt’ahoch medzi javmi vymedzenými rámcom všeobecných kategórií, ako sú občianska spoločnost', sociálna súdržnost', sociabilita, sociálne väzby, sociálne siete atd'., si však vyžadujú d’alšie teoretické rozpracovanie a empirické preskúmanie ich aktuálneho stavu v slovenskej spoločnosti. 
Ján Sopóci je profesorom Katedry sociológie Filozofickej fakulty Univerzity Komenského v Bratislave. Venuje sa problematike sociologickej teórie, najmä sociálnym nerovnostiam, sociológii politiky a sociológii organizácií.

Anna Hrabovská pracovala na Katedre sociológie Filozofickej fakulty Univerzity Komenského $v$ Bratislave. Venuje sa metodologickej priprave a počitačovému spracovaniu údajov sociologických výskumov.

\section{LITERATÚRA}

BEVORT, A. M. - LALLEMENT, M., 2006: Le capital social. Paris: La Découverte.

BOURDIEU, P., 1986: The Forms of Capital. In: Richardson, J. C. (ed): Handbook of Theory and Research for the Sociology of Education. New York: Greenwood Press, s. 239-258.

BOURDIEU, P., 1987: Distinction. A Social Critique of the Judgement of Taste. Harvard: Harvard University Press.

BOURDIEU, P. - PASSERON, J. C., 1977: Reproduction in Education, Society, and Culture. Beverly Hills: Sage.

BUNČÁK, J. - HRABOVSKÁ, A. - SOPÓCI, J., 2018: Validita sociálno-triednych klasifikácií EGP, ESeC a ESeG v slovenskej spoločnosti. Sociológia 50, č. 4, s. 367-395.

COLEMAN, J. S., 1990: Foundations of Social Theory. Cambridge: Harvard University Press.

De TOCQUEVILLE, A., 1992: Demokracie v Americe. Praha: Lidové noviny.

DŽAMBAZOVIČ, R. - GERBERY, D., 2018: Medzigeneračná sociálna mobilita na Slovensku. Sociológia 50, č. 4, s. 396-427.

EDWARDS, B. - FOLEY, M. W., 1997: Social Capital and the Political Economy of our Discontent. The American Behavioural Scientist 40, č. 5, s. 669-678.

FUKUYAMA, F., 1995: Trust: The Social Virtues and the Creation of Prosperity. New York: Free Press.

FUKUYAMA, F., 1999: Social Capital and Civil Society. Washington: IMF Conference on Second Generations Reform.

GRANOVETTER, M. S., 1973: The Strenght of Weak Ties. American Journal of Sociology 78, č. 6, s. 1360-1380.

GRANOVETTER, M. S., 1974: Getting a Job. A Study of Contact and Carreer. Cambridge: Harvard University Press.

GROOTAERT, CH. et al., 2004: Measuring Social Capital: An Integrated Questionnaire. Washington: World Bank.

HALL, P. A., 1999: Social Capital in Britain. British Journal of Political Science 29, č. 3, s. 417-462.

HALL, P. A., 2002: Great Britain: The Role of Government and Distribution of Social Capital. In: Putnam, R. D. (ed.): Democracies in Flux: The Evolution of Social Capital in Contemporoary Society. Oxford: Oxford University Press, s. 123-169.

HALPERN, D., 2005: Social Capital. Cambridge: Polity Press. 
KADUSHIN, Ch., 2012: Understanding Social Networks. Theories, Concepts and Findings. Oxford: Oxford University Press.

KELLER, J., 2009: Nejistota a důvěra, aneb k čemu je modernitě dobrá tradice. Praha: SLON.

KONEČNÝ, S., 2004: Sociálny kapitál, sociálne siete a komunálna politika. In: Lidský kapitál a investice do vzdělaní. Praha: Vysoká škola finanční a správní, s. 80-89.

KUSÁ, Z., 1997: Analýza sociálnych sietí a jej miesto v sociologickom skúmaní. Sociológia 29, č. 5, s. 479-504.

LEWANDOWSKI, J. D., 2006: Capitalising Sociability: Rethinking the Theory of Social Capital. In: Franklin, J. (ed.): Assesing Social Capital: Concept, Policy and Practice. Newcastle: Cambridge Scholar Publishing, s. 14-28.

LIN, N. - DUMIN, M., 1986: Acces to Occupations through Social Ties. Social Networks 8, č. 4, s. 365-385.

LIN, N., 1999: Building a Network Theory of Social Capital. Connections 22, č. 1, s. 28-51.

LIN, N., 2001a: Building a Network Theory of Social Capital. In: Lin, N. - Cook, K. Burt, R. S. (eds.): Social Capital. Theory and Research. New York: Walter de Gruyter, s. 3-30.

LIN, N., 2001b: Social Capital. A Theory of Social Structure and Action. Cambridge: Cambridge University Press.

LIN, N. - FU, Y. - HSUNG, R., 2001: The Position Generator: Measurement Techniques for Investigations of Social Capital. In: Lin, N. - Cook, K. - Burt, R. S. (eds.): Social Capital. Theory and Research. New York: Walter de Gruyter, s. 5781.

LIN, N. - FU, Y. - CHEN, C. J. (eds.), 2014: Social Capital and Its Institiuional Contingency. A Study of the United States, China and Taiwan. New York: Routledge.

LUBELCOVÁ, G., 2010: Sociálny kapitál ako predpoklad a dôsledok sociálneho podnikania. In: Korimová, G. - Jakab, K. (eds.): Sociálne podnikanie verzus chudoba a sociálna exklúzia. Banská Bystrica: Univerzita Mateja Bela, s. 3-12.

MATĚJŮ, P. - VITÁSKOVÁ, A., 2006: Interpersonal Trust and Mutually Beneficial Exchanges: Measuring Social Capital for Comparative Analyses. Sociologický časopis 42, č. 3, s. 493-516.

PAXTON, P., 1999: Is Social Capital Declining in the United States? A Multiple Indicator Assesment. The American Journal of Sociology 105, č. 1, s. 88-127.

PICHLER, F. - WALLACE, C., 2007: Patterns of Formal and Informal Social Capital in Europe. European Sociological Review 23, č. 3, s. 423-435.

PICHLER, F. - WALLACE, C., 2008: Capital and Social Class in Europe: The Role of Social Networks in Social Stratification. European Sociological Review 25, č. 4, s. 319-332.

PORTES, A., 1998: Social Capital: its Origins and Applications in Modern Sociology. Annual Review of Sociology 22, č. 1, s. 1-24.

PUTNAM, R. D. et al., 1994: Making Democracy Work. Civic Traditions in Modern Italy. Princeton: University of Princeton Press. 
PUTNAM, R. D., 2000: Bowling Alone. The Collapse and Revival of American Community. New York: Simon and Schuster.

ROSE, D. - HARRISON, E. (eds.), 2010: Social Class in Europe. An Introduction to the European Socio-economic Classification. New York: Routledge.

ROSE, D. - HARRISON, E. - PEVALIN, D., 2010: The European Socioeconomic Classification: a Prologomenon. In: Rose, D. - Harrison, E. (eds.): Social Class in Europe: An Introduction to the European Socioeconomic Classification. New York: Routledge, s. 3-38.

SEDLÁČKOVÁ, M. - ŠAFR, J., 2012: Koncept sociálního kapitálu. In: Sedláčková, M.: Důvěra a demokracie. Praha: SLON, s. 69- 93.

SOMERS, M. R., 2005: Let Them Eat Social Capital: Socializing the Market Versus Marketizing the Social. Thesis Eleven 81, č. 1, s. 5-19.

ŠAFR, J. - SEDLÁČKOVÁ, M., 2006: Sociální kapitál. Koncepty, teorie a metody měření. Praha: Sociologický ústav AV ČR. 